\title{
PERSEPSI MAHASISWA TERHADAP PROGRAM TAYANGAN INDONESIA BAGUS DI NET TV TENTANG BUDAYA (STUDI PADA MAHASISWA PRODI SKI)
}

\author{
Yuhaswita, dkk \\ Fakultas Ushuluddin, Adab dan Dakwah IAIN Bengkulu \\ Jalan Raden Fatah Pagar Dewa Bengkulu \\ @gmail.com
}

\begin{abstract}
Student Perceptions of a Impression Program 'Indonesia Bagus' on Net TV about Culture (Study on SKI Study Program). Student perceptions on the episode recognize the art and culture of Solok city on the aspect of livelihood that the Solok people who live in the plains of subsistence from farming while the people who live in the outskirts of Lake Singkarak work as fishermen of Bili fish and there are also traders who sell processed from Bili fish. Whereas in the Tana Toraja episode, students' perceptions on the arts aspect are people who live in rural areas making wooden statues called Tau-Tau, tau sculptures or statues of dead people to release the homesick homes left behind. Whereas in the Jayapura episode in the aspect of student art, it gives a perception that the interior people of Jayapura make paintings of flora and fauna whose raw materials are made of wood, lime, turmeric. In the episode of Tana Toraja in the aspect of art the students gave the perception of the Tana Toraja community that they believed that there were dead and toothless babies stored in a large tree that was old because in the old tree the baby got breast milk from the tree sap.
\end{abstract}

Keywords: Perception, Good Indonesia, Net TV.

Abstrak: Persepsi Mahasiswa terhadap Program Tayangan Indonesia Bagus di Net TV tentang Budaya (Studi pada Mahasiswa Prodi SKI). Persepsi mahasiswa pada episode mengenal seni dan budaya kota Solok pada aspek mata pencaharian bahwa masyarakat Solok yang berdomisili di dataran menyambung hidup dari bertani sedangkan masyarakat yang berdomisili di pinggiran danau Singkarak bekerja sebagai nelayan ikan Bili dan ada juga sebagai pedagang yang menjual olahan dari ikan Bili. Sedangkan pada episode Tana Toraja persepsi Mahasiswa pada aspek kesenian yaitu masyarakat yang tinggal di daerah pedalaman membuat patung kayu yang bernama Tau-Tau, patung tau-atau merupakan patung orang sudah wafat guna melepas rindu keluarga yang ditinggalkan. Sedangkan pada episode Jayapura pada aspek kesenian mahasiswa memberikan persepsi bahwa masyarakat pedalaman Jayapura mmembuat lukisan flora dan fauna yang bahan bakunya terbuat dali lembaran kayu, kapur, kunyit. Pada episode Tana Toraja pada aspek kesenian mahasiswa memberikan persepsi masyarakat Tana Toraja meyakini jika ada bayi yang mati dan belum bergigi disimpan pada sebuah pohon besar yang sudah tua karena pada pohon tua bayi mendapatkan asi dari getah pohon.

Kata Kunci: Persepsi, Indonesia Bagus, Net TV.

\section{Pendahuluan}

Media massa seperti televisi

mempunyai program-program siaran yang diproduksi oleh stasiun televisi yang bersangkutan, namun dengan berkembangnya ilmu pengetahuan maka dalam menyajikan program televisi bekerjasama dengan pihak lain seperti production house, bentuk kerjasama seperti memiliki prinsip saling menguntungkan sesuai dengan kontrak kerja sama. Prinsip kerja media massa seperti ini sudah digunakan oleh pengelola stasiun televisi swasta di Indonesia. Sebagaimana diketahui dan kenyataannya memang stasiun televise swasta lebih bermuatan hiburan ( sinetron, kuis, travelling dll) ketimbang misi pendidikan dan motivasi, karena informasi yang diberikan oleh stasiun televisi kepada publik berdasarkan 
pertimbangan bisnis yaitu untung dan rugi. ${ }^{1}$

Kehadiran program-program televisi mampu memberikan pengaruh yang sangat besar kepada masyarakat, baik pengaruh positif maupun negatif. Pengaruh positif maupun negatif dari program televisi bergantung kepada kondisi individu (jiwa, agama, sosial dll), berdasar pada hasil survey kepada beberapa pemuda yang telah menonton aksi kekerasan terhadap orang lain, maka hasil survey menyatakan bahwa pemuda yang telah menonton aksi kekerasan di televisi cenderung meniru aksi kekerasan. ${ }^{2}$ Di Indonesia, pengaruh media massa televisi yang mengusung berbagai program siaran yang diiringi dengan adanya iklan dari berbagai produk tentunya memberikan pengaruh kepada masyarakat, seperti pengaruh kepada tingkah laku, pandangan, persepsi dan perasaan.

Di Indonesia, laju pertumbuhan dan perkembangan media massa sangat baik dan pesat, hal ini ditandai dengan bermunculan stasiun-stasiun televisi swasta yang memiliki visi dan misi tersendiri sesuai dengan pertimbanganpertimbangan yang disepakati bersama. Selain TVRI milik pemerintah, bermunculan televisi swasta seperti SCTV, RCTI, MNCTV, Global, Metro TV, Indosiar, Trans 7 dan sebagainya. Kehadiran beberapa stasiun televisi swasta di tanah air mempunyai visi dan misi tersendiri yang direalisasikan dalam bentuk program-program siaran. Namun amat disayangkan pada kenyataanya stasiun televisi swasta lebih menonjolkan aspek hiburan dibanding aspek-aspek lainnya.
Salah satu televisi swasta yaitu NET TV, merupakan stasiun televisi yang tergolong baru hadir di tengah-tengah masyarakat Indonesia. Usia stasiun Net TV saat ini baru memasuki tahun ke tiga sejak kelahiran pada tahun 2013 lalu. Meskipun stasiun televisi ini masih tergolong baru, namun program-program tayangannya sudah banyak menarik perhatian publik. Keberadaan stasiun Net TV tidak terlepas dari orang-orang yang sudah banyak menuangkan pikiran serta idenya di stasiun Trans 7, seperti sosok Wishnutama dahulunya bagian dari stasiun Trans 7, tidak diketahui apa sebabnya, Wishnutama justru berkiprah di stasiun Net TV.

Net TV mempunyai banyak program-program tayangan yang diminati oleh berbagai kalangan masyarakat. Program-program tayangan NET TV jika diamati tidak berbeda jauh dengan stasiun Trans 7 namun hanya dikemas dengan tampilan yang berbeda dan nama yang beda. Salah satu program tayangan NET TV yang dianggap memiliki muatan/informasi pengetahuan tentang budaya dari berbagai daerah dan suku yaitu program Indonesia Bagus. NET TV walaupun usianya masih termasuk baru, namun program-programnya mendapat perhatian yang cukup baik dari berbagai kalangan masyarakat sehingga salah satu program NET TV memperoleh beberapa penghargaan dari KPI (Komisi Penyiaran Indonesia). ${ }^{3}$

Program Indonesia Bagus yang disajikan oleh stasiun NET TV setiap hari Sabtu dan Minggu jam 13.30 wib dengan durasi selama 30 menit. Program Indonesia Bagus mulai ditayangkan sejak tanggal 1 Juni 2013 hingga sekarang.4 
Program acara Indonesia Bagus merupakan acara dokumenter, program acara Indonesia bagus menyajikan dan menginformasikan tentang keadaan suatu daerah seperti keadaaan alam, aktivitas perkebunan, pertanian, kehidupan masyarakat dalam aspek sosial seperti interaksi antara anak-anak dalam sebuah permainan dan kegiatan-kegiatan adat istiadat sebuah masyarakat setempat.

Manusia merupakan makhluk ciptaan Tuhan maka hubungan antara keduanya sangat dekat. Allah juga menyatakan bahwa manusia dijadikanNya sebagai khalifah/ pemimpin di permukaan bumi dengan alasan manusia adalah makhluk yang sempurna secara fisik dan non fisik dibanding dengan makhluk Tuhan lainnya, salah satu cirri kesempurnaan manusia adalah adanya akal. Dengan akal manusia mampu menciptakan sesuatu untuk kepentingan sekaligus mempertahankan kelangsungan hidupnya.

Budaya merupakan segala sesuatu yang diciptakan oleh manusia. ${ }^{5}$ Budaya meruapakan aktivitas atau kegiatan manusia yang melibatkan fisik dan non fisik. Aktivitas budaya yang dilakukan atau dihasilkan manusia merupakan aktivitas yang telah direncanakan, dipertimbangkan dan dengan kesadaran penuh akibat-akibat atau hasil-hasilnya. Apapun yang dilakukan oleh manusia tidak terlepas dari usaha/upaya untuk menciptakan sesuatu menjadi bermakna sehingga mewujudkan kualitas hidup untuk lebih lebih baik. ${ }^{6}$

Televisi merupakan media komunikasi yang banyak menyajikan berbagai informasi yang dibutuhkan oleh banyak orang seperti informasi religi, ekonomi, politik dan sebagainya. Salah satu stasiun televise swasta yaitu NET TV menyajikan informasi tentang budaya di berbagai daerah, informasi budaya yang ditayangkan oleh stasiun tersebut tentunya sangat penting, karena dengan tayangan informasi budaya ini dapat menambah pengetahuan orang tentang budaya di daerah-daerah lain.

Pada episode Indonesia Bromo, Sekitar wilayah Gunung Bromo merupakan kawasan objek wisata, para turis lokal dan luar negeri sangat tertarik mengunjungi area Gunung Bromo. Area Gunung Bromo terlihat sangat menarik dan menakjubkan ini merupakan alasan banyak orang mendatangi Gunung Bromo. Area Gunung Bromo dimanfaatkan oleh banyak orang untuk menikmati keindahan alamnya, ada juga lokasi Gunung Bromo digunakan sebagai lokasi syuting film. Untuk menikmati Gunung Bromo dan sekitarnya digunakan transportasi tradisional seperti kuda dan transportasi modern seperti mobil Jeep terbuka. Banyaknya orang-orang yang mengunjungi Lokasi Gunung Bromo memberikan banyak manfaat bagi masyarakat sekitar, salah satunya banyak ibu-ibu yang menjajakan makanan khas daerah tersebut untuk dibeli oleh pengunjung, kegiatan ini dirasa dapat meningkatkan perekomonian keluarga. TIdak beberapa jauh dari lokasi Gunung Bromo ada perbukitan hijau yang indah, masyarakat di dekat Gunung Bromo menamakan bukit ini dengan Bukit Teletubbies.7 Di dekat Gunung Bromo terdapat sebuah daerah yaitu Tengger, masyarakat Tengger mayoritas menganut agama Hindu, dan ada juga masyarakat yang menganut agama lain. Walaupun 
masyarakat di daerah Tengger heterogen pada aspek agamanya namun nilai-nilai sosial yaitu tenggang rasa, gotong royong. Pada umumnya Masyarakat Tengger makanan pokoknya jagung, jagung diolah oleh ibu-ibu dengan sederhana dan dijadikan nasi jagung, makanan ini dipadukan dengan lauk lain yang juga sederhana, salah satu lauknya yaitu olahan jamur Grigit yang tumbuh di pohon Glantingan. Sebuah daerah dekat Gunung Bromo yaitu Lumajang, karena masyarakatnya mayoritas beragama Hindu maka banyak Pura sebagai tempat peribadatan, Pura-Pura tersebut dihiasi dengan berbagai ukiran yang merupakan karya masyarakat sekitar, ukiran-ukiran yang terdapat di sisi Pura menandakan bahwa masyarakatnya memiliki nilai seni yang sangat tinggi. Masyarakat lokal Lumajang perekonomiannya bergantung pada sumber daya alam, seperti membudidayakan berbagai jenis tanaman pisang seperti pisang Mas, pisang Agung dan pisang Kiran.

$$
\text { Program acara Indonesia Bagus }
$$
yang disajikan dalam bentuk film documenter banyak memberikan informasi, sebagaimana dicermati pada episode Indonesia Bagus: Indonesia Bromo menginformasikan aktivitas sosial kemasyarakatan yang berkaitan dengan kearifan local, aktivitas keagamaan masyarakat setempat, aktivitas mata pencaharian seperti bertani, berkebun, nelayan, aktivitas mengolah sumber daya alam sebagai bahan pangan sehari-hari seperti mengolah jagung, mengolah ulat sagu dan sebagainya.

NET TV dalam program Indonesia Bagus dirasa sangat banyak memberikan manfaat bagi semua orang terutama bagi orang-orang yang belum banyak mengetahui aktivitas kehidupan suatu masyarakat di berbagai daerah. Aktivitas kehidupan masyarakat di setiap daerah tentunya berbeda-beda dan sangat unik seperti cara mengolah makanan, menangkap ikan dengan teknik kearipan lokal, aktivitas adat dalam menyelenggarakan ritual agama, disamping itu dalam tayangan tersebut menyajikan keindahan alam di bawah laut, daratan, pegunungan, sungai dan danau yang mempesona.

Informasi-informasi aktivitas kehidupan masyarakat di berbagai daerah sangat diperlukan bagi setiap orang terutama bagi mahasiswa yang mata kuliahnya berkaitan dengan budaya masyarakat. Mahasiswa yang menuntut ilmu di bidang kebudayaan sangat memerlukan informasi tentang budaya dari berbagai daerah di Indonesia. Informasi yang disampaikan melalui media massa seperti televisi dirasa mampu menambah pengetahuan mahasiswa. Pada umumnya mahasiswa tidak banyak mengetahui tentang budaya daerahnya sendiri apalagi budaya daerah lainnya, hal ini sangat menyedihkan, akibat sikap tidak peduli dengan budaya daerahnya sendiri tanpa disadari mahasiswa telah kehilangan budayanya sendiri.

Dari pra penelitian, bahwa setelah mahasiswa menyaksikan tayangan program Indonesia Bagus di NET TV memperoleh informasi sekaligus pengetahuan tentang kondisi sebuah daerah dalam berbagai aspek salah satunya mata pencaharian masyarakat di pedalaman. Ketika mahasiswa menyaksikan episode Indonesia Bagus: 
Raja Ampat, maka mahasiswa tersebut mengetahui budaya lokal masyarakat di daerah tersebut yaitu masyarakat WTC dengan kearifan lokalnya melakukan penangkapan ikan pada malam hari, masyarakat menggunakan lampu petromat untuk menarik perhatian ikanikan di danau maupun laut, hal ini diungkapkan oleh seorang mahasiswa bernama Erni Juwita.

Saya beranggapan bahwa program tayangan Indonesia Bagus di stasiun televisi NET TV sangat bagus untuk di telaah oleh siapapun, dan sangat penting untuk diteliti, maka saya tertarik untuk meneliti program Indonesia Bagus dan bagaimana persepsi mahasiswa SKI.

\section{Pembahasan}

a. Faktor- Faktor yang Mempengaruhi Persepsi

\section{a. Perhatian (Attention)}

Perhatian adalah proses mental ketika stimuli atau rangkaian stimuli yang menonjol dalam kesadaran pada saat stimuli lain melemah. ${ }^{8}$ Perhatian terjadi karena adanya beberapa faktor yaitu faktor internal dan eksternal. Faktor eksternal berupa situasional seperti gerakan, intensitas stimuli, kebaruan, dan perulangan. Gerakan, manusia sangat tertarik pada objek-objek yang bergerak, huruf-huruf yang bergerak dalam sebuah iklan yang didisplaykan. Intensitas stimuli, manusia akan memperhatikan stimuli yang lebih menonjol dari stimuli lain. Seperti suara keras di tengah malam yang sepi dan lainnya. Kebaruan, hal-hal yang baru, yang luar biasa, yang berbeda akan menarik perhatian. Perulangan, halhal yang disajikan berulang kali jika disertai dengan variasi akan menarik perhatian.

b. Fungsional

Kehadiran persepsi akan berbeda beda pada setiap orang karena berbeda kebutuhan, pengalaman dan sebagainya. Jadi penentuan persepsi bukan berdasarkan stimuli tetapi berdasarkan karakteristik seseorang. Kondisi keilmuan seseorang yang berbeda-beda memberi makna ketika menerima sebuah pesan. ${ }^{9}$

b. Ragam Persepsi Manusia

a. Persepsi Terhadap Objek (Lingkungan Fisik)

Mempersepsi lingkungan fisik sering terjadi kekeliruan karena indera kita menipu seperti kita menyangka bumi datar padahal bumi bulat dan kita menyangka bumi diam padahal bumi bergerak dengan kecepatan tinggi. ${ }^{10}$ Latar belakang pengalaman, budaya dan Suasana psikologis yang berbeda akan membuat persepsi yang berbeda terhadap suatu objek.

b. Persepsi Terhadap Manusia

Persepsi terhadap manusia dikenal dengan persepsi sosial, persepsi sosial adalah proses menangkap arti objek-objek sosial dan kejadian-kejadian yang kita alami dalam lingkungan kita. Setiap manusia memiliki gambaran berbeda mengenai realitas di sekelilingnya. Hal penting yang berhubungan persepsi sosial, yaitu:

1. Persepsi berdasarkan pengalaman.

Orang Barat terbiasa makan menggunakan sendok, garpu, pisau ketika melihat orang Timur makan dengan tangan dan menilai orang Timur Jorok. Bagi orang Barat bersendawa merupakan 
hal tidak sopan sedangkan bagi orang Timur sendawa menandakan kebaikan bagi si tuan rumah yang menandakan makanannya sangat dinikmati oleh tamunya. 11

2. Persepsi Bersifat selektif.

Persepsi muncul dilatarbelakangi oleh faktor biologis (internal) seperti lapar, haus dsb , fisiologis (tinggi, pendek, gemuk, kurus dsb), sosial budaya (gender, agama, pendidikan, pekerjaan, status penghasilan, psikologis (kemauan, motivasi, pengharapan, kemarahan, kesedihan dsb). Semakin besar perbedaan aspek-aspek ini antar individu semakin besar perbedaan persepsi mereka mengenai realitas.12 Sedangkan persepsi juga dilatarbelakangi oleh faktor gerakan, intensitas, kontras, kebaruan dan perulangan objek yang dipersepsi. ${ }^{13}$

3. Persepsi Bersifat Dugaan.

Proses persepsi yang bersifat dugaan memungkinkan seseorang menafsirkan sesuatu objek dengan makna yang lebih lengkap dari sudut pandang manapun. Informasi yang tersedia tidak lengkap maka perlu adanya dugaandugaan yang berguna untuk menarik sebuah kesimpulan. ${ }^{14}$

4. Persepsi Bersifat evaluatif.

Terkadang seseorang menganggap apa yang dipersepsinya adalah hal yang nyata, mereka menilai bahwa menerima pesan dan menafsirkannya merupakan proses yang alamiah. Persepsi setiap orang akan berbeda dan perbedaan itu disebabkan beberapa faktor antara lain faktor politik dan kepentingan pribadi. ${ }^{15}$

5. Persepsi Bersifat Kontekstual.

Seseorang cenderung mempersepsi sesuatu rangsangan atau kejadian yang terdiri dari objek dan latar belakangnya, setiap orang memberikan persepsi sesuai dengan fokus perhatian pada sebuah kejadian. ${ }^{16}$

\section{c. Komunikasi Massa}

a. Pengertian Komunikasi Massa

Kata Komunikasi massa terdiri dari dua kata yaitu komunikasi dan massa. Kata komunikasi berasal dari bahasa Latin yaitu communico, communis yang berarti membagi, membuat kebersamaan atau membangun kebersamaan antara dua orang atau lebih. ${ }^{17}$ Secara umum komunikasi massa adalah komunikasi melalui media massa seperti media cetak dan elektronik. ${ }^{18}$ Sedangkan kata massa dalam ruang lingkup komunikasi adalah adalah penerima pesan yang berkaitan dengan media massa seperti khalayak, audien, penonton, pemirsa. Dapat dikatakan komunikasi massa adalah komunikasi melalui media massa modern seperti surat kabar, film, radio, televisi. ${ }^{19}$ Jadi komunikasi massa merupakan penyebaran pesan dengan menggunakan media yang ditujukan kepada massa yang abstrak yaitu massa yang tidak terlihat oleh penyampai pesan.

b. Fungsi Komunikasi Massa

1. Informasi

Media massa berfungsi memberikan informasi, fungsi informasi ini sangat penting dalam komunikasi massa. Komponen yang paling penting untuk mengetahui fungsi informasi adalah berita-berita yang disajilan/ditayangkan. Sebuah iklan memiliki fungsi informasi dan fungsi lainnya. ${ }^{20}$

\section{Hiburan}

Media massa dianggap telah banyak menyita waktu semua orang karena daya tarik dari aspek hiburan sangat banyak seperti nyanyian/lagu, gambar berwarna, 
lawakan. Anggapan masyarakat kita kepada media massa elektronik/televisi lebih condong pada fungsi hiburan.

3. Transmisi Budaya

Media massa menyebarluaskan hasil-hasil kebudayaan melalui pertukaran program radio, televise dan media lainnya. Pertukaran akan meningkatkan daya kreativitas guna memajukan kebudayaan nasional masing-masing Negara. Transmisi budaya mengambil tempat dalam dua tingkatan yaitu kontemporer dan historis, pada tingkatan kontemporer media masssa memperkuat nilai masyarakat karena media massa selalu memperkenalkan hal-hal baru sehingga masyarakat juga melakukan halhal baru. Sedangkan pada tingkat historis media massa mampu menggiring manusia untuk melihat masa lampau sebagai pengalaman untuk menghantar ke masa depan yang lebih baik.

\section{d. Budaya}

a. Kebudayaan

Kata budaya berasal dari bahasa Sanksekerta yaitu budhayah yang terdiri dari kata budi/buddhi, yang berarti budi atau akal dan daya yang berarti kekuatan budi. Kata budaya dalam bahasa Inggris culture, bahasa Belanda cultuur, bahasa Latin Colera yang berarti mengolah, mengerjakan, menyuburkan, mengembangkan tanah/bertani. Kata budaya akan mengalami perkembangan arti yaitu segala daya aktivitas manusia untuk mengolah, mengubah alam. ${ }^{21}$ Jadi ada beberapa pengertian kebudayaan yaitu: Kebudayaan adalah suatu keseluruhan yang kompleks yang terjadi dari unsur-unsur yang berbeda-beda seperti pengetahuan, kepercayaan, seni, hukum, moral, adat istiadat dan segala kecakapan yang diperoleh manusia sebagai anggota masyarakat. ${ }^{22}$

b. Unsur Kebudayaan

1. Peralatan dan perlengkapan hidup manusia (pakaian, perumahan, alatalat rumah tangga, senjata, alat-alat produksi dan alat-alat transportasi.

2. Mata pencaharian hidup dan system ekonomi (pertanian, perkebunan, peternakan, system produksi, dan system distribusi.

3. Sistem kemasyarakatan (kekerabatan, organisasi, politik, hukum, perkawinan).

4. Bahasa (lisan dan tulisan).

5. Kesenian (seni rupa, seni suara dan seni gerak).

6. Sistem pengetahuan.

7. Religi/kepercayaan. ${ }^{23}$

c. Wujud Kebudayaan

a. Kompleks ide-ide, gagasan, nilai-nilai, norma-norma, peraturan dll. Sifat dari wujud ide abstrak, tidak dapat diraba atau difoto. Wujud ide berada dalam kepala-kepala setiap orang yang berada dalam lingkup kebudayaan. Wujud ide sekarang sudah dapat dilihat dalam bentuk film, microfish, computer dll, wujud ide hadir selalu aktif dan berhubungan dan menjadi sebuah system budaya/culture system yang lebih dikenal dengan adat istiadat.

b. Kompleks aktivitas serta tindakan berpola dari manusia dalam masyarakat. Wujud kedua kebudayaan disebut system sosial/ social system, sistem sosial berupa aktivitas-aktivitas manusia yang berinteraksi, berhubungan serta bergaul dalam waktu-waktu tertentu. Sistem sosial bersifat konkret, dapat 
terjadi di sekitar kita, dapat diobservasi, difoto dan didokumentasi. ${ }^{24}$

c. Benda-benda hasil karya manusia, wujud ketiga dari kebudayaan yaitu kebudayaan fisik, kebudayaan fisik merupakan hasil kolaborasi wujud ide dengan wujud sistem sosial. Benda-benda yang dihasilkan oleh karya manusia bersifat nyata dari ukuran kecil hingga besar, dari sifat yang halus hingga kasar, dari volume kecil hingga besar. ${ }^{25}$ Dan sifat dari wujud kebudayaan yang ketiga ini sangat konkrit sehingga dapat diraba, difoto dan dilihat. ${ }^{26}$

\section{d. Profil NET TV}

a. Latar Belakang Pendirian Stasiun NET TV

Net TV pada awalnya merupakan sebuah PT Net Mediatama Indonesia (NET) yang bergerak di bidang energi dan sumber daya di bawah naungan Indika Energi Tbk. Indika Energi misi awalnya adalah sebagai media hiburan dan teknologi imformasi. Pada pertengahan bulan Maret 2013 PT Mediatama Indonesia mengakuisisi saham kepemilikan dari PT Televisi Anak Spacetoon sebesar $95 \%$, setelah akuisisi saham kepemilikan Spacetoon kepada NET maka pada 18 Mei 2013 siaran Spacetoon di jaraingan terrestrial menghilang. Sejak tanggal 18 Mei 2013 NET menggantikan posisi Spacetoon dan langsung memulai siaran perdananya dengan menggunakan frekuensi milik Spacetoon di seluruh bagian Indonesia. ${ }^{27}$

Saat ini stasiun Net TV sudah banyak peminat penontonnya, ini dikarenakan oleh begitu banyak programprogram siaran yang ditayangkan sesuai dengan selera masyarakat. Program siaran yang dimiliki oleh NET TV dirasakan mampu memenuhi kebutuhan masyarakat akan hiburan, pendidikan dan informasi lainnya. Kesuksesan NET TV merupakan perjuangan seorang yang bernama Wishnutama Kusubandio, sebelum berkiprah di NET TV Wishnutama pada tahun 1994 pulang ke Indonesia setelah menyelesaikan studinya di Amerika Serikat. Pada tahun yang sama ia mengawali kariernya di Indosiar sebagai Supervisor On Air Promotion, setelah berlangsung setahun sebagai Supervisor kemudian pindah ke divisi produksi sebagai Producer Director. Tidak diketahui berapa lama sebagai Producer director kemudian meningkat sebagai Executive Producer News and Production Division kemudian meningkat meningkat sebagai Production Manager. ${ }^{28}$

b. Logo Net TV

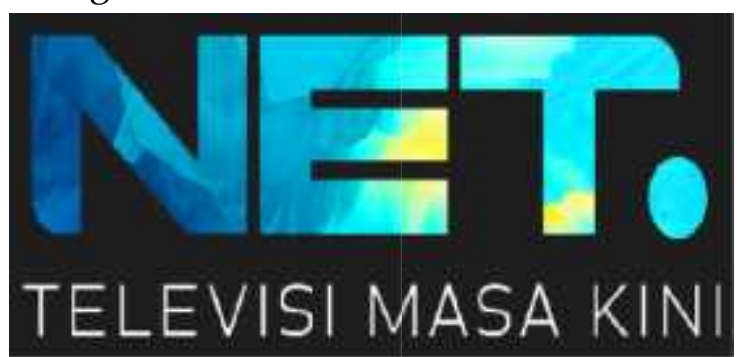

1. Arti Logo Net TV

Logo diatas merupakan logo yang digunakan oleh NET TV dengan tiga warna yaitu warna biru tua,biru muda,dan kuning. Pemilihan warna dan bentuk huruf dimaksudkan untuk membuat logo yang simple dan elegant, pemilihan warna bermaksud untuk menggambarkan variasi program yang ada di NET TV. Sedangkan penggunaan symbol titik diakhir kata menunjukan bahwa NET TV ingin menjadi televisi. yang terintegrasi dengan sosial media. Peneliti mengamati bahwa logo NET TV 
memiliki latar yang berbeda-beda yang disesuaikan dengan program tayangan yang dimiliki oleh NET TV.

2. Profil Informan

\begin{tabular}{|l|l|}
\hline No & Nama \\
\hline 1 & $\begin{array}{l}\text { Lovika Putri Ari Sandi } \\
1316431578\end{array}$ \\
\hline 2 & $\begin{array}{l}\text { Novi Susanti } \\
1316431276\end{array}$ \\
\hline 3 & $\begin{array}{l}\text { Erni Julita } \\
1316431267\end{array}$ \\
\hline 4 & $\begin{array}{l}\text { Atma Ekasari } \\
1316431265\end{array}$ \\
\hline 5 & $\begin{array}{l}\text { Leva Nollana } \\
1316431271\end{array}$ \\
\hline 6 & $\begin{array}{l}\text { Justia Asrifah } \\
1316431577\end{array}$ \\
\hline 8 & $\begin{array}{l}\text { Rizal Agusnawan } \\
1316431283\end{array}$ \\
\hline
\end{tabular}

3. Gambaran Umum Mahasiswa Tentang Kebudayaan dan Pengetahuan Perihal Program Acara Budaya di NET TV

Pada umumnya mahasiswa fakultas Adab prodi sejarah kebudayaan Islam IAIN Bengkulu berlatar belakang yang berbeda-beda seperti tingkat pendidikan sebelumnya, tingkat perekonomian yang berasal dari masyarakat pedesaan, perbedaan bahasa, perbedaan cara pandang, perbedaan prinsip hidup. Tentunya latar belakang yang paling penting yaitu perbedaan kesadaran terhadap motivasi dan tujuan hidup.

Ketika dalam aktivitas perkuliahan terutama dalam seminar di kelas akan terlihat beragam karakter mahasiswa seperti ada yang merespon perkuliahan dan ada yang tidak, dalam satu kelas hanya ada beberapa mahasiswa yang mampu merespon aktivitas belajar. Aktivitas interaksi sosial mahasiswa prodi sejarah kebudayaan Islam terkesan individu-individu karena masing-masing punya kepentingan atau tidak berkepentingan.

Kondisi mahasiswa prodi sejarah kebudayaan Islam tidak terlihat aktif untuk mendapatkan berbagai informasi dari beragam sumber media, pada kenyataannya mahasiswa kita tinggal di tempat-tempat kost yang ada di sekitar kampus IAIN namun amat disayangkan dari informasi yang diperoleh bahwa di tempat kost mahasiswa tidak di fasilitasi televisi untuk memperoleh hiburan ataupun informasi lainnya terutama tentang Channel NET TV. Pada umumnya mahasiswa tidak mengetahui keberadaan channel NET TV apalagi program tayangan Indonesia Bagus. Kenyataannya mahasiswa masih banyak yang tidak peduli betapa pentingnya informasiinformasi budaya yang ditayangkan oleh stasiun televise dan mereka lebih mementingkan persoalan yang tidak penting. Mahasiswa sejarah kebudayaan Islam secara umum sudah mengetahui beberapa hal yang berhubungan dengan kebudayaan.

Ketika dalam proses penayangan ulang program tayangan Indonesia bagus di lokasi/kelas masing-masing informan memberikan respon dan reaksi yang beragam hal ini terjadi sebagaimana telah diungkapkan sebelumnya. Apapun yang terjadi selama proses penayangan ulang berlangsung hingga selesai tentunya akan menghasilkan sesuatu yang beragam, maka pada akhirnya masing informan memberikan persepsi, tanggapan terhadap tayangan yang peneliti berikan, seperti memberikan tanggapan yang singkat tanpa bisa menceritakan ulang apa yang telah dilihat oleh panca inderanya 
dan ada pula informan yang mampu menceritakan apa yang dilihat dan di dengarnya. Pada umumnya informan menyambut baik adanya tayangan ulang ini karena informan mendapatkan informasi/pengetahuan yang mungkin belum diperolehnya.

4. Persepsi Mahasiswa pada Episode Mengenal Seni dan Budaya Kota Solok Sumatera Barat

4.1 Aspek Perekonomian/Mata Pencaharian
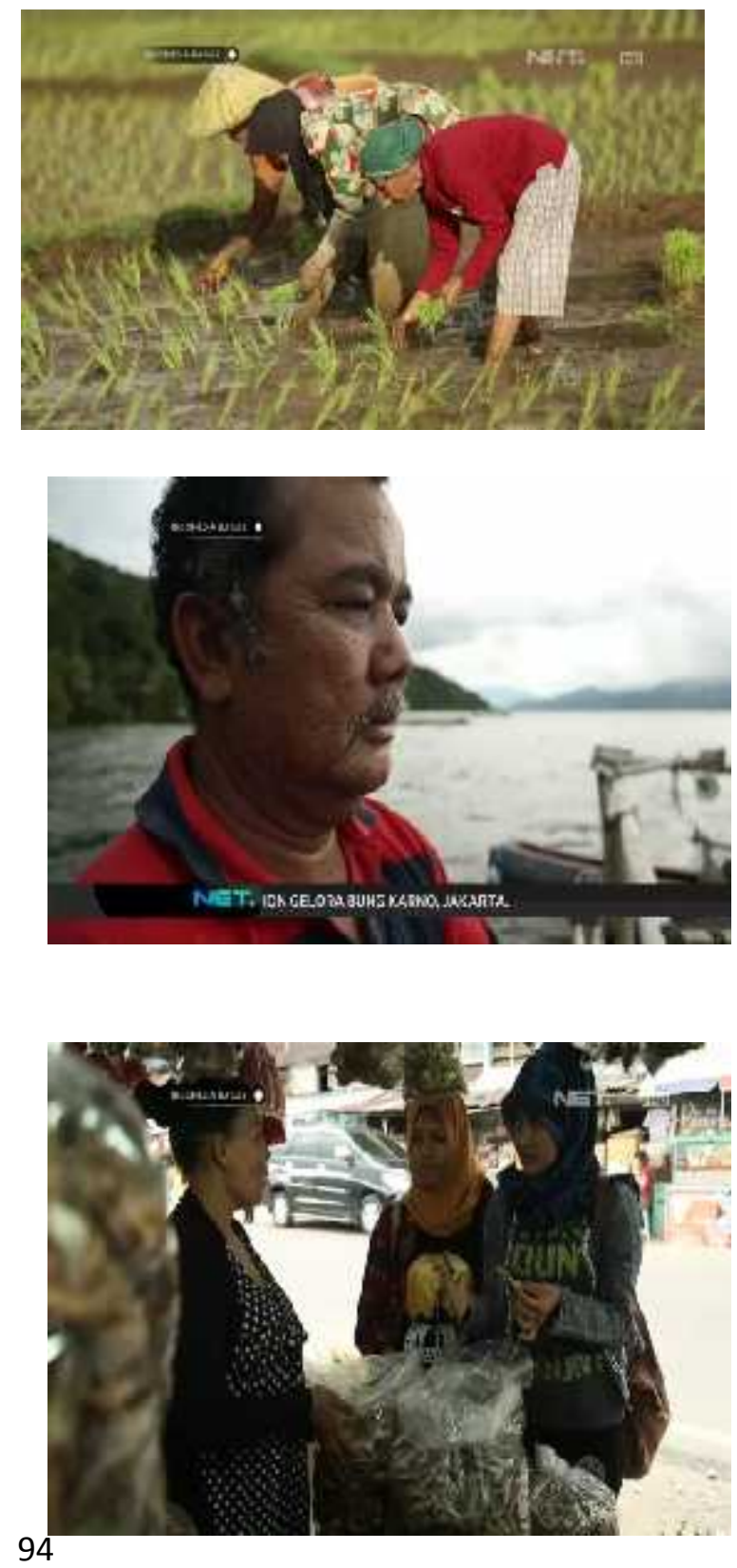

Pada Episode Mengenal Seni dan Budaya Kota Solok Sumatera Barat, masyarakat yang berada di daerah dataran rendah kota Solok pada umumnya aktivitas mata pencahariann sebagai petani di sawah sedangkan di pinggiran danau sebagai nelayan dan pedagang olahan ikan Bili, hal ini dapat terungkap dari beberapa informan yaitu:

1. Justia Asrifah

"Solok berarti bagus, kota kecil (Padang), pada umumnya masyarakat Solok mata pencahariannya bersawah dan nelayan, masyarakat rata-rata turun ke sawah tidak laki-laki dan perempuan semua turun ke sawah." 29

\section{Lefa Nollana}

"Dan juga mata pencaharian nelayan di mana mencari ikan di sungai, mencari ikan pada jam 4-5 pagi, pendapatan sampai 1-2 liter ikan, kalau di jual 1 liter 100.000 kalau sudah digoreng dan diolah harga ikan Bili sampai 120.000." 30

\section{Lovika Putri Ari Sandi}

"Masyarakat Solok sangat dikenal dengan beras Soloknya dan sebagian masyarakatnya bermata pencaharian sebagai petani dan dilihat ke daerah danau Singkarak sebagian masyarakatnya bernelayan." 31

\section{Atma Ekasari}

"Pada umumnya mata pencaharian masyarakat Solok bercocok tanam (tani) terutama padi yang terkenal dengan beras Solok yang rasanya ranca bana /elok, bagus dan pulen. Selain itu juga masyarakat Solok bermata pencaharian sebagai nelayan (ikan Bili)." 32

5. Nursela 
"Sama seperti desa di beberapa daerah mata pencaharian setempat adalah petani terutama petani sawah, di Solok terkenal dengan berasnya, beras daerah setempat dijual di berbagai daerah bahkan di ekspor ke luar negeri. Selain petani masyarakat setempat juga mencari uang dengan mencari ikan atau nelayan." 33

6. Lopita Jayanti

"Mata pencaharian dari Solok yaitu bertanam padi/petani sawah, danau Singkarak juga sebagai objek wisata dan menjadi sumber mata pencaharian menangkap ikan di danau." 34

4.2 Aspek Kesenian

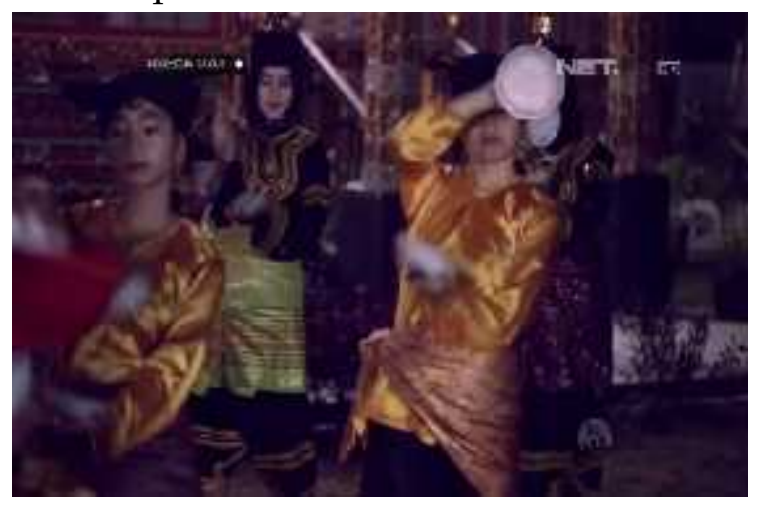

1. Erni Julita

"Di Solok mempunyai ciri khas mengenai kesenian seperti di saat ada acara-acara tersebut biasanya ada tariantarian yang biasa disebut dengan tari turun ke sawah, tarian tersebut mempunyai arti dan alasan khusus bagi masyarakat Solok, tarian turun ke sawah ini menunjukkan kegiatan petani dan cara mensyukuri nikmat." 35

2. Nursela

"Sumatera Barat menampilkan budaya yang namanya Baralek Gadang maknanya adalah supaya yang muda dapat mengenal budaya mereka, budaya yang ditampilkan dari adat pernikahan sampai kematian. Acara ini digelat setiap setahun sekali setelah melakukan pawai kebudayaan tokoh adat makan sebelum makan mereka berbalas pantun menggambarkan rasa ramah tamah dan sopan santun, selain itu ada juga tari togok (lilin) piring, tari dipentaskan saat pengucapan rasa syukur terhadap hasil pertanian." 36

\section{Lopita Jayanti}

"Mata pencaharian dari Solok yaitu bertanam padi/petani sawah, danau yang terkenal di Solok yaitu wisata alamnya, danau Singkarak juga sebagai mata pencaharian penangkap ikan di danau."37 4.3. Persepsi Mahasiswa pada Episode Tana Toraja

4.3.1 Aspek Perekonomian/Mata Pencaharian
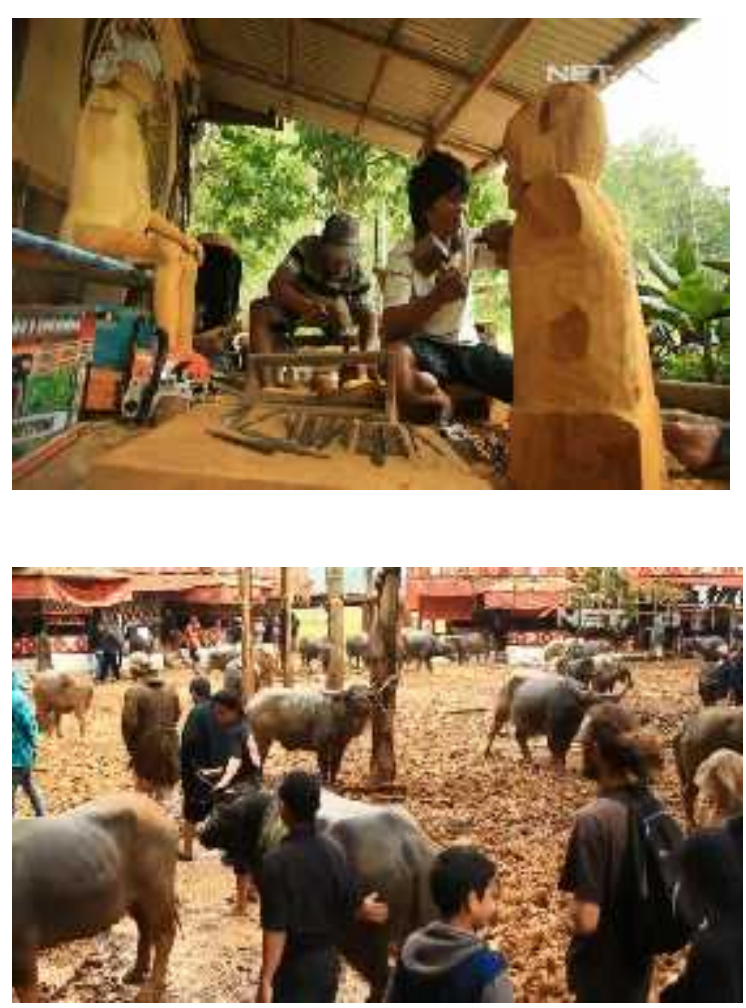

1. Lovika Putri

"Mata pencaharian masyarakatnya sebagian besar menjadi pemahat kayu 
yang dipesan dari keluarga yang berduka untsuk membuat patung yang sama persis dengan jenazahnya beserta asesorisnya." 38

2. Novi Susanti

"Pada masyarakat Toraja pada umumnya ada yang sebagai petani, bercocok tanam dan ada masyarakat yang sebagai pembuat tau-tau atau patung orang yang sudah meninggal dan kayu tersebut terbuat dari kayu bambu." 39

3. Atma Ekasari

"Karena banyaknya pembuatan patung maka secara tidak langsung masyarakat Toraja melakukan pembuatan tau-tau yang bisa menghasilkan dalam mata pencaharian masyarakat Toraja, para penjual sapi, kerbau menjadi sebuah keuntungan dalam mencari mata pencaharian." 40

\subsubsection{Aspek Kesenian}

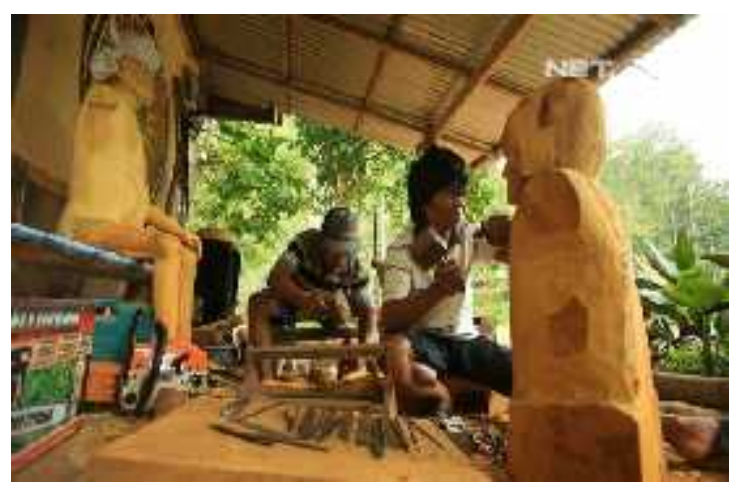

\section{Novi Susanti}

"Pada masyarakat Toraja pada umumnya ada yang sebagai petani, bercocok tanam dan ada masyarakat yang sebagai pembuat tau-tau atau patung orang yang sudah meninggal dan kayu tersebut terbuat dari kayu bambu."

\subsubsection{Aspek Keyakinan/Agama}

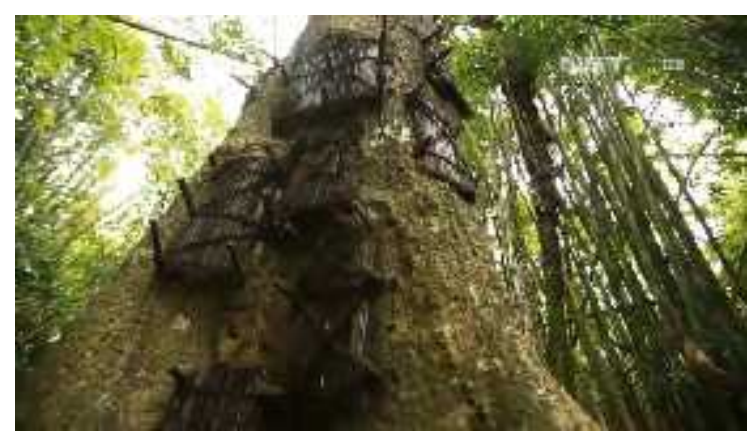

1. Rizal Agusnawan

"Sebuah keyakinan unik dalam masyarakat sehingga masyarakat mempercayai bahwa Kambira ialah makam bayi yang belum bergigi untuk dipercaya sehingga kalu bayi dikubur dalam kayu Kambara adalah dipercayai bayi akan kenyang. ${ }^{41}$

2. Lovika Putri

"Kambira adalah kuburan bayi yang belum punya bergigi yang dipakai sejak 1950-an, dimana kuburan ini mayat/jenazah bayinya dikubur di dalam pohon yang bergetah karena masyarakat yakin getah kayu menggantikan air susu ibu bayi dan mereka yakin bahwa bayi yang dikubur tidak akan kelaparan." 42

4.3.6 Persepsi Mahasiswa Pada Episode Jayapura

4.3..1 Aspek Perekonomian/Mata Pencaharian
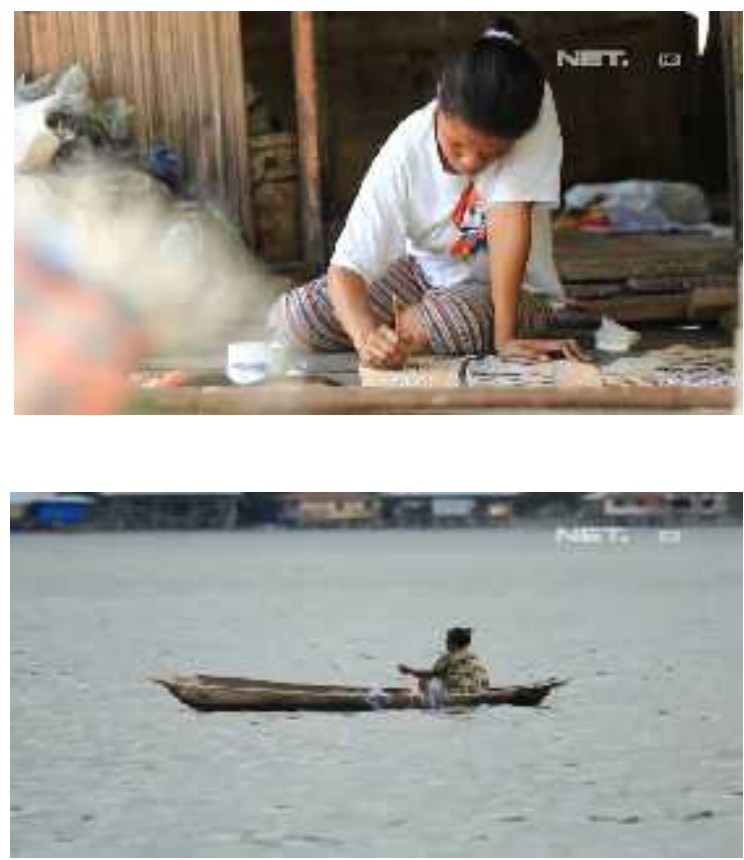

1. Lefa Nollana

"Mata pencaharian di Jaya Pura adalah mencari ikan di laut dan membuat lukisan dari kulit kayu." 43 


\section{Atma Ekasari}

"Kesenian yang ada di Jaya Pura yakni lukisan kayu yang terus diproses menjadi sebuah lukisan yang memiliki berbagai motif yaitu salah satu motif Pow yang melambangkan lukisan keluarga kerajaan. Secara tidak langsung dari hasil lukisan kayu ini masyarakat Jaya Pura menjadi sebuah mata pencaharian mereka." 44

\subsubsection{Aspek Kesenian}

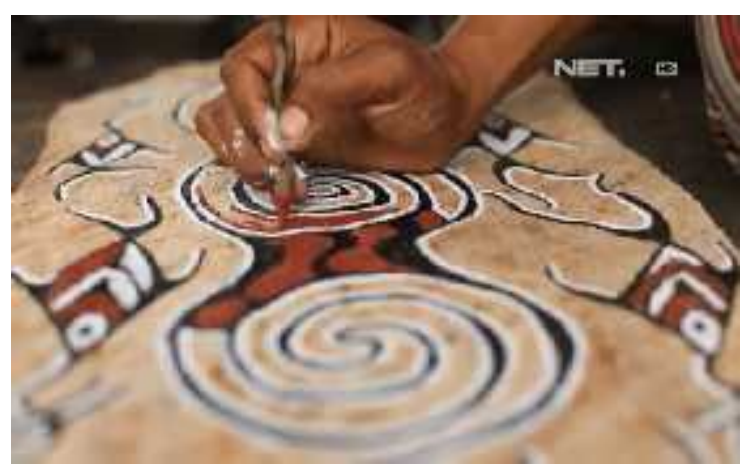

\section{Justia Asrifah}

"Kesenian membuat pada lukisan kayu, kayu berasal dari Kambou, lukisan banyak motif seperti ikan, babi yang artinya kebersamaan setiap keluarga. Melukis dengan menggunakan teknik yang mahir, warna untuk melukis dibuat alami seperti sirih, kunyit." Dan menambahkan, setelah menonton atau melihat dari berbagai kebudayaan yang ada di Indonesia Bagus sangat memberi ilmu pengetahuan serta wawasan yang diberikan oleh tayangan channel NET TV dari kebudayaan yang ada seperti pada kesenian, kesenian sangat banyak tidak terhitung di Indonesia ini. Kesenian atau budaya yang mencirikan khas daerahnya sendiri seperti budaya pernikahan." 45

2. Atma Ekasari
“Kesenian yang ada di Jaya Pura yakni lukisan kayu yang terus diproses menjadi sebuah lukisan yang memiliki berbagai motif yaitu salah satu motif Pow yang melambangkan lukisan keluarga kerajaan. Secara tidak langsung dari hasil lukisan kayu ini masyarakat Jaya Pura menjadi sebuah mata pencaharian mereka." 46

\section{Kesimpulan}

Kesimpulan yang dapat diambil dari data penelitian yang dilakukan yaitu:

Aspek Mata Pencaharian.

Pada episode mengenal seni dan budaya kota Solok Sumatera Barat, menyambung hidup dengan bertani di sawah, menjadi nelayan ikan dan pedagang olahan ikan Bili. Pada episode Danau Toba, masyarakat suku Batak hidup dengan bekerja sebagai bertani, pengrajin seni patung kayu dan menenun Ulos.Pada episode Tana Toraja masyarakat menyambung hidup dengan bertani, berladang selain itu juga sebagai pekerja seni membuat patung kayu Tautau. Episode Jayapura, masyarakat menyambung hidup dengan berladang, nelayan di danau Sentani dan sebagai pekerja seni lukis dari bahan kayu.

Aspek Kesenian

Pada episode Mengenal seni dan budaya kota Solok, bidang seni terkenal dengan tari turun ke sawah dan tari togok/lilin. Pada episode Danau Toba, bidang seni masyarakat suku Batak membuat kain tenun Ulos dan membuat miniatur rumah adat suku Batak dan patung-patung kayu. Masyarakat suku Batak mempunyai seni tari yaitu tari TorTor. Episode Tana Toraja ada mayarakatnya yang membuat patung tau- 
tau yang terbuat dari kayu, patung ini replica dari orang yang sudah meninggal. Episode Jayapura, masyarakat membuat lukisan dari lembaran kayu yang sudah diproses, lukisan ini dibuat dari bahan yang alami dengan motif flora dan fauna.

Aspek Keyakinan

Episode Tana Toraja, masyarakat Toraja meyakini jika ada bayi yang tidak belum bergigi meninggal maka dikuburkan di celah sebuah pohon besar dan tua karena pohon tua dianggap mampu member makanan keada bayi dengan getahnya

\section{Endnote}

${ }^{1}$ Deddy Iskandar Muda, Jurnalistik, op.cit, h. 8

2Fajar Junaedi, Komunikasi Massa, Pengantar Teoritis, (Yogyakarta, Santusta: 2007), h. 103

32013, program dokumenter terbaik (nominasi), 2014 program TV Feature budaya terbaik (menang), 2015 program TV Feature terbaik (menang).

4http@//www.google.com=kapan program Indonesia-bagus, diunduh tanggal 9 Pebruari 2016

${ }^{5}$ Astrid S. Susanto-Sunario, Globalisasi dan Komunikasi, (Jakarta, Pustaka Sinar Harapan, 1995), h. 114

6Musa Asy'arie, Manusia Pembentuk Kebudayaan Dalam Alquran, (Yogyakarta, LESFI, 1992), h. 113

7Teletubbies yaitu sebuah program hiburan anak-anak atau lebih dikenal dengan kartun anak-anak, kartun ini banyak diminati oleh semua kalangan terutama anak-anak. Teletubbies sosok boneka-boneka lucu terdiri dari empat bersaudara yang berbeda warna, sifat, dan kepandaian.
8Jalaluddin Rahmat, Psikologi Komunikasi, (Bandung, PT Remaja Rosdakarya: 2009), h. 52

${ }^{9}$ Ibid, h. 57

10Deddy Mulyana, Ilmu Komunikasi Suatu Pengantar, (Bandung, PT Remaja Rosdakarya: 2007), h. 184

${ }^{11}$ Ibid, h. 192

12Ibid, h. 197, Faktor motivasi, setiap orang akan berbeda persepsi sesuai dengan status dan kondisinya. Seperti ketika dua orang laki-laki yang berbeda status dan kondisi bertemua dengan seorang perempuan yang berpenampilan necis. Maka dua laki-laki akan berbeda persepsi terhadap perempuan tersebut sesuai dengan motivasi yang dimilikinya.

13Sebuah objek yang bergerak lebih menarik perhatian daripada objek yang diam. Maka orang banyak lebih menyukai menonton program siaran televise daripada membaca komik merupakan gambar diam. Objek yang penampilannya berbeda dengan lainnya akan menarik perhatian seperti orang bule yang dikerumi oleh orang kulit hitam.

${ }^{14}$ Ibid, h. 201

${ }^{15} \mathrm{Ibid}, \mathrm{h} .207$

16Ibid, h. 211

${ }^{17}$ Hafied Cangara, Pengantar Ilmu Komunikasi, (Jakarta, PT Raja Grafindo Persada, 2014), h. 20

${ }^{18}$ Nuruddin, Pengantar Komunikasi Massa, (Jakarta, Rajawali Pers:2009), h. 4

${ }^{19}$ Onong Uchjana Effendy, Dinamika Komunikasi, (Bandung, PT Remaja Rosda Karya: 2008), h. 50

${ }^{20}$ Nurudin, Pengantar Komunikasi Massa, (Jakarta, PT Raja Grafindo Persada: 2009), h. 66 Informasi merupakan kegiatan untuk mengumpulkan, menyimpan data, fakta dan pesan, opini dan komentar sehingga orang dapat mengetahui keadaan yang terdi di luar dirinya. Hafied Cangara, Pengantar Ilmu Komunikasi, (Jakarta, Raja Wali Pers: 2014), h. 70

${ }^{21}$ Elly M, Setiadi, Ilmu Sosial dan Budaya Dasar, (Jakarta, Kencana Prenada 
Media Group, 2007), h. 27 Koentjaraningrat, Pengantar Ilmu Antropologi, (Jakarta, PT Rineka Cipta, 1990), h. 181 menyatakan kata budaya mengalami perkembangan menjadi budidaya yang berarti daya dari budi. Budaya berupa cipta, karsa dan rasa. Sedangkan kebudayaan adalah hasil dari cipta, karsa dan rasa. Lihat juga Atang Abd Hakim dkk, Metodologi Studi Islam, Bandung, PT Remaja Rosdakarya, 2000), h. 27 Lihat juga di Astrid S. Susanto- Sunario, Globalisasi Dan Kebudayaan, (Jakarta, Pustaka Sinar Harapan, 1995), h. 114 hal yang sama juga diungkapkan oleh Muhammad alfan, kata kebudayaan dalam bahasa Yunani "paideia" yang berarti pendidikan. Sedangkan di India kata bermakna kebudayaan yaitu "sarvodaya" yang berati segenap usaha manusia untuk mencapai perkembangan integral dan seimbang. Muhammad Alfan, Filsafat Kebudayaan, (Bandung, Pustaka Setia: 2013), h. 20 ${ }^{22} \mathrm{Ada}$ beberapa pengertian kebudayaan, yaitu:

1. Warisan sosial atau tradisi.

2. Cara, aturan, dan jalan hidup manusia.

3. Penyesuaian manusia terhadap alam sekitarnya dan cara-cara menyelesaikan persoalan.

4. Hasil perbuatan atau kecerdasan manusia

5. Hasil pergaulan atau perkumpulan manusia.

Atang Abd Hakim dkk, Metodologi

Studi Islam, Bandung, PT Remaja Rosdakarya, 2000), h. 28

${ }^{23}$ Atang Abd Hakim dkk, Metodologi

Studi Islam, Bandung, PT Remaja Rosdakarya, 2000), h. 32

${ }^{24}$ Alfan menambahkan pada wujud kebudayaan yang kedua berhubungan dengan tindakan berpola manusia dari waktu ke waktu. Muhammad Alfan, Filsafat Kebudayaan, (Bandung, Pustaka setia, 2013), h. 54
${ }^{25}$ Koentjaraningrat, Pengantar, h. 186-187

26Muhammad Alfan, Filsafat Kebudayaan, (Bandung, Pustaka Setia, 2013), h. 54

27https://eprints.uns.ac.id/16920/b

ab.3_1 pdf diunduh tanggal 5 Agustus 2016

28http://id.wikipedia.org/wiki/wis hnutama. diunduh tanggal 5 Agustus 2016

${ }^{29}$ Wawancara pada tanggal 4 Juni 2016

${ }^{30}$ Wawancara pada tanggal 4 Juni 2016

${ }^{31}$ Wawancara pada tanggal 4 Juni 2016

${ }^{32}$ Wawancara pzda tanggal 4 Juni 2016

${ }^{33}$ Wawancara pada tanggal 4 Juni 2016

34 Wawancara pada tanggal 4 Juni 2016

35 Wawancara pada tanggal 11 Juni 2016

36 Wawancara pada tanggal 11 Juni 2016

37Wawancara pada tanggal 11 Juni

2016

${ }^{38}$ Wawancara pada tanggal 23 Juli

2016

${ }^{39}$ Wawancara 23 Juli 2016

${ }^{40}$ Wawancara pada tanggal $23 \mathrm{Juli}$

2016

41Wawancara pada tanggal $23 \mathrm{Juli}$

2016

2016

42Wawancara pada tanggal 23 Juli

2016

43Wawancara pada tanggal 30 Juli

${ }^{44}$ Wawancara pada tanggal 30 Juli

2016

${ }^{45}$ Wawancara pada tanggal 30 Juli 2016

${ }^{46}$ Wawancara pada tanggal $30 \mathrm{Juli}$ 2016

\section{Daftar Pustaka}

Alfan, Muhammad, 2013, Filsafat

Kebudayaan, Bandung, Pustaka Setia 
Asy'arie, Musa, 1992, Manusia

Pembentuk Kebudayaan Dalam Alquran,

Yogyakarta, LESFI

Cangara, Hafied, 2014, Pengantar Ilmu Komunikasi, Jakarta, PT Raja Grafindo Persada

Effendy, Onong, Uchjana, 2008, Dinamika Komunikasi, Bandung, PT Remaja Rosda Karya

Hakim, Atang Abd dkk,2000, Metodologi Studi Islam, Bandung, PT Remaja Rosdakarya

Junaedi, Fajar, 2007, Komunikasi Massa, Pengantar Teoritis, Yogyakarta, Santusta

Koentjaraningrat, 1990, Pengantar Ilmu Antropologi, Jakarta, PT Rineka Cipta Moleong, Lexy 2007, Metodologi Penelitian Kualitatif, Bandung, Remaja Rosdakarya

Nuruddin, 2009, Pengantar Komunikasi Massa, Jakarta, Rajawali Pers

Susanto-Sunario, Astrid S, 1995, Globalisasi Dan Komunikasi, Jakarta, Pustaka Sinar Harapan

Setiadi, Elly M, 2007, Ilmu Sosial dan Budaya Dasar,(Jakarta, Kencana Prenada Media Group,

Rahmat, Jalaluddin, 2009, Psikologi Komunikasi, Bandung, PT Remaja Rosdakarya 